\title{
EDITORS' SPECIAL
}

\section{Evolutionary Thought in Management and Organization Theory at the Beginning of the New Millennium}

\author{
A Symposium on the State of the \\ Art and Opportunities for Future Research
}

\author{
JOHANN PETER MURMANN \\ Northwestern University \\ HOWARD E. ALDRICH \\ University of North Carolina \\ DANIEL LEVINTHAL \\ SIDNEY G. WINTER \\ University of Pennsylvania
}

\begin{abstract}
The beginning of a new millennium provides a welcome opportunity to take stock of the accomplishments, open questions, and most promising research avenues of evolutionary models in management and organization theory. Johann Peter Murmann has invited Howard Aldrich, Daniel Levinthal, and Sidney Winter to appraise the state of the art in evolutionary research and where scholarly efforts should go in the new millennium. The panel also clarified their positions by answering questions that Johann Peter Murmann solicited from the scholarly community in response to the panel's dialogue.
\end{abstract}

Keywords: evolutionary theory; management theory; organization theory; firm capabilities

\section{JOHANN PETER MURMANN:}

\section{A Short History of Evolutionary Thought in Management}

The beginning of a new millennium provides a welcome opportunity to take stock of the accomplish- ments, open questions, and most promising research avenues for evolutionary models in management and organization theory. I invited three leaders in evolutionary thought to appraise the state of the art in evolutionary research and to articulate their views on where research should go in the new millennium. 
Because my goal was to cover a broad spectrum of evolutionary thought in management and organization theory, I recruited panelists with diverse backgrounds-management, sociology, and economics.

As part of the open-systems revolution in organization theory, evolutionary models blossomed in the 1970s. Within a short period of time, scholars formulated evolutionary accounts to explain phenomena ranging from the micro to the macro levels of organization. Inspired by the work of Donald Campbell (1960, 1969), Karl Weick (1979), for example, developed a social psychological theory of how individuals coordinate their actions. Weick's theory drew heavily on the variation, selection, and retention logic of evolutionary models. What Weick did for individuallevel organizing processes Howard Aldrich (1979) attempted for the level of entire organizations. Aldrich formulated a comprehensive application of the variation, selection, and retention model to the study of how organizations change over time. In Aldrich's evolutionary model, organizations flourish or fail because they are more or less fit for the particular selection environment in which they operate. Rather than explaining organization success and failure by appealing to managerial intentions, Aldrich's evolutionary account focused on whether organizations have the appropriate traits for a particular selection environment, irrespective of whether managers intended these traits. Testimony of vitality of evolutionary models, a recent collection of essays edited by Joel Baum and Bill McKelvey (1999) in honor of Donald Campbell, examines Campbell's influence on organization theory. The 25 scholars who contributed to the volume provide a broad survey of his blind variation and selective retention model in organization studies and canvass the theoretical as well as methodological problems that have surfaced since its original formulation four decades ago.

Although Weick and Aldrich were mostly inspired by Donald Campbell, Richard Nelson and Sidney Winter's (1982) evolutionary explanations of economic organization built on the Carnegie School's routine-based models of organizational action (Cyert \& March, 1963/1992; March \& Simon, 1958; Simon, 1976) and Joseph Schumpeter's (1934, 1942/ 1950) body of work. In the middle of the century, Schumpeter was the most prominent advocate of the position that economic change needed to be conceptualized as an evolutionary process, although he rejected the Darwinian formulation as a useful model for the social sciences. Unlike most other economists,
Nelson and Winter (1982) took organization theory seriously in thinking about firms and made it an integral part in the explanation of how industries and their structures change over time (Dosi \& Winter, in press; Murmann, in press; Murmann \& Homburg, 2001).

Selection-based explanations for the development of industries also formed an integral part of Michael Hannan and John Freeman's $(1977,1984)$ work in the population ecology of organizations and Bill McKelvey's (1982) complementary work on organizational taxonomy. Although there has been relatively little systematic research on taxonomy, a large empirical literature has developed around Hannan and Freeman's ecological models (for overviews, see Amburgey \& Rao, 1996; Carroll \& Hannan, 2000; Singh \& Lumsden, 1990).

The work of James March and his students (Herriott, Levinthal, \& March, 1985; Levinthal \& March, 1993; March, 1999) on organizational learning is typically not classified under the rubric of evolutionary theory. But it clearly has a strong evolutionary flavor. As his introductory essay to Joel Baum and Jitendra Singh's (1994) edited volume on the Evolutionary Dynamics of Organizations makes plain, March has been a close observer of evolutionary theorizing, and his coworkers have readily moved from work on organizational learning to work that bears directly on advancing evolutionary theory. Dan Levinthal's (1997) work on fitness landscape, for instance, deals with the fundamental issue in evolutionary theory of how to conceptualize selection processes. Levinthal (1992) has also employed evolutionary theory to advance our understanding of competitive processes.

Nelson and Winter (1982) pioneered the systematic application of evolutionary models to economics change. Their book An Evolutionary Theory of Economic Change has had a great influence in a number of fields. In the field of economics, the book has found a larger readership in Europe than in the United States (Cantner, Hanusch, \& Klepper, 2000; Dosi, 2000; Saviotti \& Metcalfe, 1991; Silverberg \& Soete, 1994, p. 1743; Witt, 1993). For the 20th anniversary of $A n$ Evolutionary Theory of Economic Change, the Danish Research Unit for Industrial Dynamics organized a conference in which 170 papers were presented in honor of Nelson and Winter. A selection of these papers will be published in a special issue of Industrial and Corporate Change and Research Policy. (Many of the 170 papers are available on the Web at http:// www.business.auc.dk/druid/conferences/nw/) 
But arguably the book's greatest impact has been in the field of business and corporate strategy. This is not all that surprising given that the book's opening sentence places firms at the center of attention: "In this volume we develop an evolutionary theory of the capabilities and behavior of business firms operating in a market environment" (italics added). Nelson and Winter's (1982) work has inspired important theoretical and empirical work in the field of strategy such as Teece, Pisano, and Shuen's (1997) Dynamic Capabilities and Strategic Management, Kogut and Zander's (1992) Knowledge and the Speed of the Transfer and Imitation of Organizational Capabilities: An Empirical Test, and Zander and Kogut's (1995) Knowledge of the Firm, Combinative Capabilities, and the Replication of Technology. The literature around the resource-based theory of the firm (Barney, 1991; Wernerfeld, 1984) also has been heavily influenced by Nelson and Winter's (1982) evolutionary views on firm development.

Complementing Nelson and Winter, Robert Burgelman's (1991, 1994) work on how Intel was transformed from a company that was organized around making memory chips to a company that was organized around integrated circuits has laid the groundwork for articulating a rigorous theory of selection processes within the firm. Steven Klepper and his colleagues (Klepper \& Simons, 1997, 2000a, 2000b; Holbrook, Cohen, Hounshell, \& Klepper, 2000) have conducted a series of very detailed empirical studies of the development of the automobile, tire, and the TV receiver industries. One of the very few studies that simultaneously tracked variation and selection processes at the level of individual human beings, the firm, and the industry was Langton (1984). In The Ecological Theory of Bureaucracy: The Case of Josiah Wedgwood and the British Pottery Industry, Langton examined concurrent changes in the cognitions and behavioral patterns of individual employees, the structural characteristics of the Wedgwood firm, and the British pottery industry as whole.

Nelson and Winter (1982) have also had a great influence on organization theory precisely because they offered a realistic portrayal of the microbehavior (organizational routines) that can account for systemlevel effects (e.g., market outcomes). Organization theories in general-not just the evolutionary approaches-in many instances have not provided coherent and satisfactory links between micro and macro processes. I have asked the panel to articulate their views on how to address this theoretically important aggregation problem.
A key element of any evolutionary theorywhether it be in linguistics, biology, culture, technology, or industry-is a mechanism for creating novel things. At the center of Howard Aldrich's (1999) new book Organizations Evolving lies the question of how new organizations emerge. Aldrich notes that organizational scholars have done an excellent job explaining how things work in organizations that have been around for a while, but not how they came to be that way. He laments too little work on the genesis of organizations, organizational populations, and communities. Without understanding why and how social units emerge, we miss, in his view, the connection between ongoing creative ferment in human societies and the particular realizations of it in organizations. In Organizations Evolving, Aldrich also argues that the evolutionary approach serves as an overarching framework within which the value of other approaches such as the ecological, institutional, interpretive, organizational learning, resource dependence, transaction cost economizing approach can be recognized and appreciated (p. 42). In light of the recent debate about the value of making the field of organization studies more paradigmatic (Pfeffer, 1993; Van Maanen, 1995), the question of whether evolutionary theory can serve as an overarching framework for studying organizations clearly deserves to be discussed in more detail.

Aside from appraising the state of the art and future prospects of evolutionary thought in management theory, I asked the panel to address three specific questions in preparing for our conversation. These three questions strike me as particularly important in enhancing our understanding about evolutionary approaches.

(a) To what extent do evolutionary models take managerial intent into account?

(b) What are the appropriate units of selection?

(c) How successful have evolutionary theorists been in linking the micro and macro processes of social organization?

\section{HOWARD ALDRICH:}

\section{Beakless Chickens, Celibate Priests, and Selection Logic}

In the spirit of what Peter charged us with, I want to lay out three or four provocative points. For the benefit, in particular, of people who are still wondering what this is all about, I thought I would focus on fun- 
damental issues. I want to talk about why it's important to look at the world through a selection lens.

Evolutionary theory is about selection logic. Indeed, selection logic drives what evolutionary theorists do. Why is that important? Well, an example that I've become enamored of recently is multilevel selection: What does it mean to take seriously not just the idea of multilevel analysis but also the idea of multilevel selection? (Sober \& Wilson, 1998). What does that mean in particular? Well, it means being concerned with the fact that some behaviors or activities on the parts of units-they can be people, groups, teams, organizations - can decrease their individual fitness within their unit but, in fact, increase the fitness of the unit itself. So, for example, people in organizations, or organizations in populations, can actually engage in behavior that lowers their fitness, that is, decreases their longevity, their profitability, or their effectiveness as units. But in the same moment, in the same process, their action raises the level of fitness of the larger entity. Thus, evolutionary analysts must try to figure out the relative contribution of the opposing forces in determining long-run outcomes.

Sometimes it's easier to grasp selection logic when you're not worrying about humans in the equation, and so I have borrowed an example from Sober and Wilson (1998). Envision flocks of chickens on an egg farm. Some time ago, a problem for the egg production industry was how to get more eggs out of a flock of chickens. Chicken farmers followed a classic, individual-level selection procedure in the past, focusing on the productivity of individual chickens, and thus they missed a golden opportunity to increase production.

Chickens in the wild roam free (well, as free as you can be in farmyards). They run around in flocks and they have a lot of room to themselves, so that territoriality is not a major issue. Modern chickens, as found in egg production farms, are raised in cages. They're very close together, they get in each other's way, and they peck each other a lot. In fact, chickens in egg farms have to be debeaked to prevent them from killing each other. Nonetheless, the mortality rates are often about $50 \%$ in a flock.

So the egg production people, with the old-style understanding of selection, said, "Well, why don't we raise the productivity of our flocks by simply picking out the chickens that lay the most eggs, breeding them, and then over time we'll get a higher level of egg production." Unfortunately for the selectors, it turns out that genetically they're already at the limit of what chickens can do. In fact, using selection at the individual level had a very perverse effect. Picking the chickens that were the greatest egg producers resulted in actually decreasing egg production. Why is that? Well, animal ethnographers went into the chicken houses with notebooks and tape recorders to see what the chickens were actually doing. What did they discover? They found that the most productive chickens could be laying more eggs because they succeeded in killing the other chickens, or at least preventing them from eating. They're just the more aggressive and nastier chickens. Thus, selection at this level produced nasty chickens and unproductive flocks.

A breakthrough came when chicken farmers started thinking in multilevel selection terms. Rather than individual chickens, chicken flocks are actually the relevant unit. They are social groups. They don't just lay eggs as individuals, but rather as flocks. Therefore, after the selectors recognized this pattern, they changed their selection process. Instead of choosing individual chickens that were productive, they chose flocks of chickens that had high output and bred those flocks with other flocks. The result? Over time, egg production increased dramatically. And as a side consequence, which the humanist in me appreciates, they found they could stop cutting off beaks, because the chickens stopped killing each other. Thus, here we have a classic example of multilevel selection: Working at the level of individuals produces a perverse result at the group level because you create a group that's actually less productive than before. By contrast, selecting for the entire group produces, in this case, better chickens; well, more output, anyway.

Celibate priests are another puzzle. Sociobiologists are often puzzled by anomalies like celibate priests, because it would seem absurd for an organization or a movement-a social movement that wants to spread itself-to have key members who are celibate. By definition, celibate priests, in theory at least, don't leave heirs. The celibate priests are decreasing their genetic fitness; that is, their gene lines die out if they're the last sons in their family. This seems on its face an absurd situation, but only if one thinks at the level of the individuals.

But what are celibate priests doing for their group? Well, celibate priests at the group level are incredibly important because of their deeds and what happens when others observe them. They go around doing good deeds. In turn, the good deeds, in Susan Blackmore's (1999) terms, lead other people to want to emulate them, and so it looks like it's a good thing to 
be a Catholic priest. They have time to perform all these wonderful deeds because they aren't raising children, and they also have time to proselytize. Accordingly, social movements, and any organizations that are seeking to expand themselves rapidly, can use people like this: people whose behavior decreases their individual fitness but at the level of the group actually makes them more effective in competition with rival groups.

I've deliberately chosen dramatic examples to make a point about multilevel selection analyses. Other examples are perhaps not quite so gory or sacrilegious. For example, when we examine promotion policies within firms we can see the same thing at work. Selecting on the basis of hiring and promoting the most aggressive members can have the perverse effect of actually decreasing the fitness of the firm if that policy leads to internal conflict, an overall nasty atmosphere, and people who don't enjoy working there anymore.

For an example at the population level, I turn to collective action in units like trade associations and other collective bodies (Aldrich, 1999). A new industry benefits enormously if some of its members are willing to take the lead in organizing the collective action required to create a trade association. Again, this action is something that looks like a deficit for individual firms in the short run. If they weren't engaged in such acts they could use those resources elsewhere more productively. Their activities as self-sacrificing entities make the trade association possible, solidify the trade association's political power, and therefore increase the legitimacy and the long-run viability of the population.

We can go a bit further and ask ourselves, How do such actions spread in populations? It's quite possible that organizations can learn these behaviors in one population and spread them to another population. It's possible also that the most powerful organizations are most likely to engage in such actions, and that is, in fact, what happens to trade associations. In that case, they're actually, in the long run, probably helping themselves as well. It doesn't really matter if they benefit individually or not, however. The point I'm making is that they're engaging in actions that at the collective level have a payoff, regardless of the individual cost.

So back to my first point-multilevel selection. Multilevel selection means that we take seriously the possibility that what benefits, or alternatively what decreases, the fitness of a unit within a larger unit actually raises the fitness of the larger unit. Evolutionary explanations can't always be straightforward. It's not a matter of adding things up. In these cases, we have to consider what the net balance is between multiple levels of selection.

The second issue is what's being selected. Sid [Winter] and Dick [Nelson] (1982) many years ago proposed the idea of routines and competencies as units of selection. Bill McKelvey (1982) proposed something similar, called a "comp." Think about what that means: If selection works on routines and competencies, then what are organizations? Organizations are just the temporary repositories of routines and competencies. They're just vehicles, or carriers. The distribution of these routines and competencies depends upon the selective survival and growth of organizations, but the competencies "don't care" about the organizations, except insofar as it advances their proliferation.

Dawkins's (1976) concept of selfish genes captured this idea well. From this point of view, coldly, calculatingly, routines and competencies don't care about organizations. They don't have to. All that matters for those routines and competencies is that an organization lives long enough for them to be propagated.

Analysis becomes more complicated when we see things like epistasis, raising the possibility that routines and competencies don't come in isolation but rather in bundles. What happens if it's bundles of these things that matter and not the routines or competencies individually? The situation becomes even more complicated when we recognize that it's the expression of routines and competencies that matters, not their representation, regardless of how they might appear inside the organization (perhaps in the form of policy manuals, norms, and values that are carried by individuals as understandings). Selection is by consequences. Selection forces work on the expression of these routines and competencies, whether isolated or in bundles. It's not the representations that are important but rather their expression in actions and deeds.

The other possibility is that it's not really routines and competencies but whole organizations that are the unit of selection. What if we took seriously the resource-based view of the firm. This is something that just actually came to me recently when I was reading Nicolai Foss's $(1993,1997)$ works, in which he argued that a resource-based view of the firm has a lot to say to evolutionary theory. Following the resource- 
based view, imagine that a firm is in fact a unique bundle-an idiosyncratic bundle of routines and competencies. In that case, routines and competencies rise or fall only when the organization rises and falls.

The question is, in that case, can we talk about routines and competencies as units of selection anymore? How can we, if they're so tightly coupled to the fate of the organization? If the resource-based view is really pushed to its extreme, to the limit of the argument the strategists make, what a firm needs to do is work towards uniqueness-toward idiosyncrasy-and toward identity that separates the firm from everyone else. Then, can we use routines and competencies anymore as units of selection?

One last, even more radical notion: contained in a book by Susan Blackmore (1999) called The Meme Machine. Let's accept the argument that, in fact, she's right, and let's take routines and competencies as the equivalent of memes. Humans, decisions, strategies, and so forth would not be our focus anymore. Those are all, again, simply ways in which routines and competencies make copies of themselves. It's a fairly radical way of thinking about selection logic. It means that if we truly focused on routines, competencies, practices, and so on, we would NOT follow people anymore in our research. Instead, we would follow how competencies spread, replicate, and insinuate themselves into organizations. People would disappear from our equations.

\section{SIDNEY WINTER:}

\section{The Progress of Evolutionary Thinking in Economics and Management}

I propose to look both backward and forward, but primarily at things that relate to the proposal that Richard Nelson and I put forward in our book in 1982. First, there are a number of areas in which quite significant progress has been made that is helpful to or in some way supportive of that proposal. Some of the people who made the contributions that I will note here thought they were making contributions to our endeavor. Others thought something quite different; I don't care. This is the selfish evolutionary theory. It gobbles up these contributions regardless of their intent. Let me put one other qualification up front; that is, I'm not implying at all that we know enough about any of these subjects. There's vastly more work to be done in all of these areas, but I think if you compare where we are now with where we were when Dick and I wrote An Evolutionary Theory of Economic Change, I think there has been a very substantial advance.

First of all, on the nature of routines, and specifically of operational routines, I think that we really have a reasonably good picture of the way those routines work at the operational level. That picture has developed with one very important contribution at the experimental level by Cohen and Bacdayan in their 1994 paper, which essentially showed that they could reproduce at the level of a dyad, and under a suitably controlled experimental situation, many of the phenomena that we think of as being characteristic of organizational routines. We also learned quite a lot, I think, from the discussion and the literature on lean manufacturing. That literature gave us quite a detailed view of differences in practices as they existed between the Japanese auto industry, for example, and the U.S. auto industry before lean manufacturing diffused, and then of how those transitions occurred. And in particular, I'm a big fan of Paul Adler's (1993) paper on the Nummi plant, which has a lot of really fascinating detail that is informative about the nature of routines. And finally, and more broadly, I've had an interest in quality management (Winter, 1994), and I think the quality management movement has also revealed quite a bit about the nature of operational routines.

I use the term "capabilities" to refer to higher level and more significant aggregates of routines, which are more a matter of managerial discretion in their exercise. We've also learned a good deal about capabilities and dynamic capabilities of various sorts. There is a literature on new product development, for example, that is an important area of dynamic capabilities and a famous paper by Clark, Chew, and Fujimoto (1987) on that subject. There's a very congenial paper that economic historian Steve Usselman (1993) wrote on IBM and the origins of its capabilities and dynamic capabilities, which is actually written from the evolutionary theory point of view. And there are a number of other contributions on capabilities, some of which have recently appeared in a volume edited by Giovanni Dosi, Richard Nelson, and myself (2000) titled The Nature and Dynamics of Organizational Capabilities.

A third topic is idiosyncratic learning and the sources of variety. One of the things I think that Howard's puzzle about unique bundles of routines 
actually alludes to is the issue of how we get diverse solutions to the same basic task or problem in a collection of organizations. I don't think, Howard, that the fact that the solutions are different means that we have to abandon routines as a level of analysis, but it was an important gap in our earlier thinking that we really didn't have a very clear image of the nature of the variety that exists. In this case, I think that actually the theoretical contribution has been most illuminating, and I refer in particular to my colleague Dan Levinthal and his work on NK modeling of complexity in organizations. That gives a very interesting picture, I think, of how complexity and different starting points and local search as mechanisms of generation of organizational routines could give you very much the kind of picture we seem to have where we have different, more or less equiperforming, solutions to a given problem.

One kind of glaring omission in our 1982 book was the failure to think about evolution, and industry evolution in particular, in a historical context. This is a real head-thumper kind of realization after the fact. The realization is that if you look at historical situations, a lot of the struggle, survival-of-the-fittest kind of thing that goes on in an industry is something that has a particular historical setting. And as the organizational ecologists have shown us so clearly, there's a lot of activity in terms of birth and death processes early on in an industry's history. So if you really want to understand the way the market system and the feedback from the marketplace provides the selective force that operates to shape what is actually happening, the examples that are really powerful are examples from a historical context of relatively early stages in industry evolution or, of course, later stages where there is some innovation which renews the whole process. That is a very important perspective on evolutionary processes in economics, and there is a substantial literature now on industry evolution in which very important contributions have been made by Steve Klepper and colleagues (Klepper 1997; Klepper \& Simons 1997, 2000a, 2000b; Holbrook et. al., 2000).

There is also a very interesting discussion about the sources of variance in firm-level profitability, a literature that goes back to Dick Schmalensee's (1985) contribution in the AER [American Economic Review]. It was really introduced to the strategy field by Dick Rumelt (1991) and followed up by a number of authors. Ned Bowman with Connie Helfat (2001) and Anita McGahan and Michael Porter (1997) and others have looked at this issue. This is friendly information, as far as I'm concerned, because the general thrust of this literature is to the effect that a lot of the variation that we see in performance as measured by profitability (ROA) [return on assets] resides at deep levels in organizations. That's convenient, because the kind of theory that Nelson and I put forward gives you some reasons to think that there might be cross-sectional differences and persistence in the way things happen at the plant level, say, or at the business unit level. But those reasons aren't so clearly operative at the corporate level. What the variance analysis turns up is the fact that there's a lot of persistence and a lot of the variance coming from the business unit level, not so much from the corporate or industry level.

The last item on my list of areas of progress is an area where the research program in evolutionary economics has intersected in an interesting way with the recent vogue for something called "knowledge management." A basic idea in evolutionary economics is that firms tend to grow by doing "more of the same." In fact, in most of our simple models firms employ exactly the same operational routines through time, in the absence of deliberate innovation efforts. Similarly, firm growth means employing the same operational routines on a larger scale; the implicit assumption is that they expect to increase profit by doing so. In the models, firms have no difficulty in replicating their routines either in time or in space.

The interest in knowledge management arises from the same motivational perspective, namely, that firms can profit by leveraging their existing knowledge. In contrast to the models, however, the assumption in knowledge management is that the reuse of existing knowledge is quite a problematic process in an organization. Consistent with the previous observation that the sources of variety are deep inside organizations, the empirical evidence arising from knowledge management efforts indicates that firm knowledge is far from homogeneous internally and that there are numerous obstacles to internal transfers of routines. Gabriel Szulanski (1996, 2000) has done important work illuminating those obstacles, and a lot of insight into the role of routines as sources of advantage gets generated as a byproduct of this research. There remains a substantial challenge of developing evolutionary models that correspond to the evidence better than the simple ones do.

So much for the review of progress. Let me turn now to issues for the future. Trying to think about research priorities leads me first to the observation 
that the questions that are interesting from the viewpoint of evolutionary economics straddle several different fields-and which of them you think are most interesting probably depends on the field you are coming from.

The work Nelson and I (Nelson \& Winter, 1982) did was conceived as a contribution to economics, particularly relevant to the economics of industrial organization, technological change, and economic growth. All we could do at the time was to try to sketch in the picture-in terms of concepts and methods as well as the substance of the phenomena of economic change. Although in absolute terms there have been many contributions that fill in that sketch, the total is still very modest relative to the size of the agenda. For example, chapter 9 of the book uses simulation to explore a model that is essentially an evolutionary version of the kind of description of the economy that appears in the growth theory models of orthodox economics. Some closely related analytical tools are sketched in chapter 7. We didn't do the job very completely or well, and there was plenty of room for doing more and better work on the problem. Very little of that follow-up has actually been done. There are many other examples of parts of the evolutionary program for economics that require foundation work, not to speak of opportunities for application. But the great bulk of that will probably remain undone, short of a paradigm shift in economics that doesn't seem to be happening.

The impact of evolutionary economics thinking has been greater in organization theory and strategic management, and hopefully, that implies a greater likelihood of some real attention to the agenda. Under the former heading, certainly the exploration of multilevel selection processes is a key heading, both for empirical work and modeling. The question of where routines and capabilities come from, the learning processes and contextual factors that give rise to them, deserves vastly more attention than it has received. The relevant circumstances and processes are clearly quite diverse, so the attention has to be spread among the different contexts and challenges-established firms versus new ones, "hard" technological versus "soft" administrative routines, "new to the world" versus new to the market, firm, or unit, and so forth.

Actually, the latter sort of work is also highly relevant in the context of strategic management, and some important contributions have been made in my department. My colleague Harbir Singh supervised a series of dissertations that I call the "How companies learn to X" series. The authors and X's are Maurizio Zollo, now at INSEAD, on bank acquisitions; Prashant Kale, at Michigan, on technical alliances; and Phanish Puranam, at London Business School, on high-tech acquisitions. The empirical setting in each case involves companies that are facing a series of tasks of the same general type, and the question is whether they are learning as they go and if so, how and whether it makes a difference. Mostly they are learning, and it is interesting to see how it happens and the difference it makes. Zollo and I (Zollo \& Winter, 2002) have a related conceptual paper in Organization Science. But under the strategic management heading, the big issue that I want to raise has to do with the evolutionary perspective on business success. I will get to this a bit later.

How one thinks of the research priorities also depends a good deal on one's time horizon. As a believer in the scientific program of evolutionary social science, I feel very strongly the crying need for high-quality science on foundation issues. That would include, at one extreme, careful empirical studies of organizational learning at a very micro level, and at the other, sophisticated mathematical modeling of evolving systems as stochastic processes. But the opportunities for application of evolutionary thinking, for example, in understanding the evolution of capabilities and their relationship to profitability, are very tempting targets. I would feel somewhat irresponsible in recommending that someone, especially a young scholar, attend to the foundation issues rather than seizing those low-hanging fruit. But I still hope that some researchers will be attracted to the foundation issues.

Before proceeding to the discussion of the evolutionary perspective on success, I want to flag two gaps in understanding that frame important research issues regardless of the disciplinary perspective from which you approach the topic. First, an obviously appealing empirical program for evolutionary economics is to characterize how firms differ in their routines and how those differences are reflected in differences in growth and profitability. But at present we lack an adequate approach for characterizing routines in ways that would be useful for statistical analysis. It is important here not to be distracted by counsels of perfection. Keep in mind the large and arguably successful literature on diffusion of innovations, where the problem of operationalizing "innovation" exists and 
is very similar to the problem of operationalizing "routine." For the most part, the answer provided doesn't get much beyond the name of innovation and the yes-or-no questions of whether innovation does or does not exist in firm $j$ at time $t$. It would be very nice to be able to do a lot better than that, but "somewhat better" would be at least "nice."

The second of the gaps relates to a big difference in perspective between evolutionary economics and organizational ecology. The valuable empirical work done in the latter field has concentrated almost entirely on count data-births, deaths, and the number of organizations in existence-and on large populations. Organizational forms become more prevalent when the birth rate exceeds the death rate. An organizational routine, however, can become more prevalent through net births or the differential growth of organizations that possess the routine or through changes in routine in existing organizations, perhaps driven by imitation. (See Nelson and Winter, 1982, chapter 7, for formal analysis. Note that this discussion presumes that we can answer Howard's point about recognizing "the same" routine in different organizations, even though no two routines are really the same.) Given the extreme skewness of firm size distributions, and the related fact of relatively high concentration in most industries, it seems likely that the latter two mechanisms are a lot more important quantitatively than the first. This, however, is an empirical question that calls for systematic study.

I turn now to the evolutionary perspective on business success. My first point about this draws on the advertising slogan of the state lotteries: You can't win if you don't play. But in competition in the marketplace, "playing" is a lot more complicated than buying a lottery ticket. A lot of it is about acquiring the necessary capabilities. It is usually the possession of the relevant capabilities that distinguishes those who are playing from those who are not. So it's relatively easy to give the reasons why a great many firms are noncontenders. It's just as easy as it is to give the reasons why, although we don't know who will win the gold medals in the upcoming Olympics, we do know that I will not be among them. Those are relatively straightforward issues. When it comes to sorting out the potential winners among those who have made the investments, that's a much more challenging task. Whereas it is true that you can't win if you don't play, what the lottery slogan does not go on to say is- you're damned unlikely to win if you do play. And that's the harder part of the problem.

Now, the evolutionary perspective says: We're skeptical about foresight in the evolutionary school. We think people don't see the future very well. You should try to refrain from relying on the assumption that they see the future well when you try to explain their behavior. As you look at these examples of who are the players and who are not players, it turns out, time after time, that the crucial investments occurred for reasons that were not clearly associated with a clear image of the course of the future in which these investments were going to pay off, in which they were going to be successful. Very frequently you see what the biologists call preadaptation, that is to say, that the capabilities and the orientations were put in place by causal forces or contingencies that had relatively little relation to the subsequent evolution in which those behaviors proved to be successful.

The final point here is this. It is true that good guesses and judgments are important success factors, along with persistence in building the necessary capabilities. But if you're trying to understand the sources of success, the fact that it's often hard to tell a good judgment from a good guess (i.e., good luck) is a major stumbling block.

This evolutionary perspective is a skeptical one in terms of the feasibility of deriving useful strategic guidance. And in that sense, the evolutionary perspective might be a little bit hostile to the agenda of strategic management. I'm even more hostile than that.

If you look at the literature in management, in strategic management in particular, you see that there is a lot of enthusiasm for coming up with secrets of business success. There's a lot of pressure to come up with business success secrets. There's a lot of pressure to claim that you did even if you didn't. As a part of this phenomenon, we have on these slides a list of what I consider to be undesirable attributes, which are notoriously, in my view, prevalent in much of our research. And I'm not condemning anybody in particular; I'm just saying there's a lot of this. There's a lot of ex post storytelling, there's a lot of looking for the attributes of successful firms without looking whether they are present in unsuccessful firms, or looking at the issue of success syndromes .... You see people mining secrets from cases of extraordinary success. A very reasonable thing to do on its face, but you should have in the back of your mind the mental model of those 10,000 people 
flipping coins. After several rounds of coin flipping you've got somebody in the 10,000 people who's got a terrific record of coin flips. If you don't look at the sample from which the extraordinary success is being drawn, you don't actually know whether you have an extraordinary success or not from a statistical point of view.

There's a lot of flexibility in the way we measure success, there's a lot of flexibility in the time frames that people choose for their accounts of success, and lastly, there's one great, lurking danger. The claim is often made that what businesses are about is shareholder value. If shareholder value is what businesses are about, then we ought to be looking at stock market valuations. There, when we discuss the persistence of success or its origins, we're up against the efficient markets hypothesis and the generally strong evidence in support of the efficient markets hypothesis, notwithstanding some contrary evidence. That evidence suggests that it is very hard to come up with an understandable basis for predicting success and presumably, therefore, for prescribing for success.

I think that both the evolutionary program and the program of research in strategy, generally, would be considerably strengthened if we could stop doing the stuff I just mentioned. We need higher standards for the demonstration that there actually are such things as useful strategic advice and useful strategies, which are truly a matter of choice and discretion, that are being followed by some firms and not by others. That would mean that we would take the evolutionary perspective on success seriously, of course inviting challenges. Without challenges it wouldn't be any fun, but we need to insist that the standards of proof for claims that there is useful advice to be given or that there are "rules for riches" ought to be set very high. I think the financial economists have had a lot of success with that approach, taking the efficient markets hypotheses as a very strong null that you had to fight with very intensely, and I think we could learn a lot from that.

In the end, I think, let me underscore one pointI'm not saying it's all luck: Remember that to be a player, you have to make timely investments in the right capabilities-that we understand. The issue is, among those who are players do we have a really strong basis for saying what succeeds in the sense of discriminating a successful player from an unsuccessful one? I think we could do a lot to advance both the evolutionary program, refining its perspective on the role of foresight, discretion, and choice in these pro- cesses, and also advance the program of strategic management if we would take this course.

\section{DANIEL LEVINTHAL:}

\section{The Evolution of Evolutionary Ideas in the Academy of Management}

As management theorists and social scientists more broadly, we puzzle about why things are the way they are, and my sense is basically we've come up with two big ideas. And the two big ideas are some notion of God and some notion of evolutionary processes. There are a variety of manifestations of these basic starting points. Perhaps the most prominent manifestation in the social sciences of the godlike idea is the neoclassical theory of the firm. In that theory, we don't quite live in paradise. Indeed, much of the analysis is about exactly how far we are from paradise due to the constraints of property rights and information sets. In the evolutionary perspective, there's a notion that in fact there are many possible worlds. The world we live in is not necessarily any more special or virtuous than these other possibilities. How we arrive at this particular world becomes an important question. In particular, ideas of path dependence have been central in much of our thinking - the idea that the state of the system at time $t$ constrains, informs, and affects probabilities of realizations of the state at time $t+1$. Less central, but also really quite important, is the notion that selection processes only occur over what's out there. So in some sense, we don't only have a problem of survival of the fittest, we have a problem of the arrival of the fittest. Some of Howard's work in his recent book talks a bit about this genesis problem, the emergence of the variety. A particular form of this question of the arrival of the fittest that is quite central for biologists is the process of aggregation. How you go, say, from a single-cell entity to a multicellular entity. This higher order entity then forms the grist for the mill of subsequent selection processes.

One feature of the recent history of evolutionary thought in management is its success. It is the focus of increasing energy and attention. Ironically, I think it's done quite well in part because it has some similar properties as one of its foils-neoclassical economics. One of the properties they share in common is that they're essentially context free. It is this property that allows economists to invade lots of niches. They can 
take over political science, and they can push into some aspects of sociology. Similarly, evolutionary theorists can invade a variety of niches ranging from social psychology to game theory to industry evolution. Another part of its appeal, again a feature that I think it shares with neoclassical economics, is the ability to aggregate. The ability to go from the characterization of lower level processes to higher level entities. Clearly, the kind of aggregation mechanism is a bit different in the two lines of work, with evolutionary theorists relying on selection processes as opposed to equilibrium notions, but at some broad level the intellectual engine has some important similarities. This issue of micro/macro linkages links up with many of the same themes that Howard started us off with and raises questions of what constitutes the unit of selection.

First, what are we selecting? As suggested by Howard's comments, we have to distinguish between selecting across organizations versus selecting for organizations. If an organization is simply a repository of routines, there doesn't necessarily have to be any interesting properties about the organization itself. In some sense, what we would be selecting on is demography - the demography of routines. Some organizations may have a better set of routines and, in turn, a higher probability of survival, but there is nothing particularly organizational about the process. Firms get profits and are wonderful and special because they have some interesting individual attributes. They have a cherished brand name. They have the capacity to miniaturize electronics and so on. However, in such a perspective the firm is a bundle of these resources, these capabilities, but the firm itself doesn't really have any meaning. So it's important, then, to think about in what ways the organization itself might be an interesting and meaningful unit of analysis for selection.

Here are some candidate answers to that question. I think an important starting point in thinking about this question is to recognize that firms receive profits and losses from the environment. Individual activities within organizations do not. The clever proposal you sent to senior management, the politicking and backbiting that you engaged in late Friday afternoon, they themselves are not directly rewarded from the environment. A critical attribute of the organization is, in some sense, its mechanisms of credit assignment. How can it go from some sense of overarching profit and loss and then rain rewards, whether individual- level incentive rewards or rewards in the sense of resource allocation onto these various initiatives and actions that are transpiring within the organization? Such a mechanism is truly an organizational-level property. Selection pressure could then operate on different mechanisms of credit assignment that are out there, as opposed to the demography of resources or demography of relatively independent routines. In that sense, there is an important distinction between the natural selection environment of the marketplace versus the artificial selection environment that may be occurring inside the organization.

Another kind of basis, as it's suggested in some of Sid's comments, is the fact that we don't just have necessarily isolated routines. We might have assemblies of these routines. The Fordist production system or the Toyota production system is not an individual routine. It is an assemblage, a package, of a variety of kind of behaviors and action patterns that take place inside the organization. These broader assemblages are properties of the organization, and selection on these assemblages is distinct from selection on the basis of individual traits and the distribution of these individual traits across organizations.

A related notion is the idea of mutual adaptation. By being placed in the same organizational context, procedures and actors may become adapted to one another, resulting in heterogeneity that is truly an organizational property. Such an argument, in some sense, turns transactions-costs thinking on its head. Relation-specific qualities do not induce a particular governance structure; rather, the governance structure induces mutual adaptation and, in turn, relationspecific skills and capabilities.

Let me conclude by addressing some of the issues that Sid raised about the management implications of evolutionary perspectives. Let's consider how we might possibly link the images of godlike design on the one hand and on the other hand ideas of blind evolution. Perhaps, to some degree, we can engineer these evolutionary processes. Consider the frequently discussed need for organizations to balance processes of exploration and exploitation. Such manipulation is not going to be a precise engineering of the evolutionary process but a broad awareness of the affect of alternative organizational policies on the dynamics of firm evolution. One particular level of influence is the presence of multiple levels of adaptation and selection, through which parallelism and hierarchy help resolve the tension of the exploration/exploitation tradeoff. 
Experimentation can be present at some low level, while the subset of these experiments that prove successful can be exploited at a higher level in the entity. This intraorganizational selection process suggests at least a modest role for conscious intervention in the evolutionary process. More generally, what do the actors themselves actually think? We are considering the evolution of organizational entities comprised of individuals, not proteins. This difference may influence how we wish to model such processes.

\section{DEBATING THE ISSUES}

Murmann: I am curious to hear how much you agree with each other's views. Howard, what do you make of Sid's and Dan's observations?

Aldrich: I want to amplify what Sid said about the dangers of retrospective reconstruction, or pursuing what I would call outcome-based research. That is, picking winners, or picking organizations that are survivors at any point. Any cross-sectional analysis that you do has the inherent bias of being outcome driven. Typically, a researcher using this style searches for-or ransacks, one could say - the organization's history to find the antecedents to the "success." If one works forward, of course, you get a very different answer, using what I would call the event-driven model. I can think of very few research programs that have avoided this problem, with perhaps the exception of the ecologists who use an event-driven process to design their research. But what's lacking, mostly, is a recognition that we actually need to have an eventdriven research process to construct an evolutionary explanation with data, which means having information about the successive states of whatever it is we're observing, whatever the unit might be-teams, groups, organizations, or populations - and we need to have repeated measurements over a long period of time.

We need to recognize that after every trial there could be divergent events. Every event sparks not just one possible consequence but many possible consequences. That kind of research design is extremely costly and requires us to spend a lot of resources on data collection, unless we're in the laboratory. Think about something like the Panel Study of Income Dynamics or the National Longitudinal Survey of Youth. We don't yet have an organizational equivalent. We almost have, actually, with the data from the United States' Census Bureau's BITS [Business Information Tracking Series], formerly known as the LEEM [Longitudinal Establishment and Enterprise Microdata] files. This data set links firms over different years in a very primitive way.

We don't have many such research designs. Accordingly, almost everything we do in our field has some element of an outcome bias, and that's a very important thing to recognize. I am less sanguine than Sid. He was talking as if we have more information than we actually have. The best study is something like Mike Cohen's studies of people playing cards in a lab, right? It's great stuff but it's just a start. We have to recognize the incredible challenge selection logic poses to the resources we currently put into our research designs. We're not talking here an incremental change. We're talking a major discontinuity.

Winter: I want to make one comment about Howard's observations and one about Dan's. First of all, Howard's question about whether routines sort of disappear as units of selection if, in fact, they are unique either individually or unique as bundles seems to me to point to a problem that is more serious for the resource-based view [RBV] than it is for evolutionary theory. I think that the RBV may overemphasize that "uniqueness" word in its account. It seems to me that if that critique were valid, it would pretty well dispose of genes as units of selection in biology as well-since, apart from the case of identical twins, individuals are unique in their genetic composition once you look at all the dimensions. So I don't think that is a fundamental problem. But as a matter of operationalizing the program, it is a very real research task to understand how routines, while not being precisely identical from one organization to another, are similar, yet different in selectively significant ways, and I think you have to able to incorporate both of those facts in a proper evolutionary theory.

Turning to Dan, I think he said something shocking, so I'm going to ask if he really meant that. Dan says that organizations considered as collections of routines are not really organizations, and to that I say wait a minute, Dan ... routines are coordination. A lot of people thought what organization was about was coordination. Coordination is a very, very important phenomenon of the world. The complicated things that organizations accomplish for us are accomplished with extremely refined coordination in many cases, and those coordination phenomena are very much illuminated by the study of routines, and they're particularly illuminated by those people playing cards in Michael's [Cohen] lab. So I think we have a lot of understanding about what the nature of high coordination is, and how it arises, as I suggested in my retrospective on the issue of operational routines. I think I heard Dan say that organization is about credit assignment. Is that what you said, Dan?

Levinthal: I didn't intend to be shocking. The intent was to suggest that if organizations were comprised of isolated routines, we might have some interesting group selection but not necessarily interesting organizational selection. I then tried, perhaps not coherently, to argue how we might go beyond such isolated routine action to assemblages of routines and broader notions of organizational capabilities. Routines themselves are obviously about coordination. They become an even more powerful source of organizational heterogeneity when they adhere and become a broader assemblage. The more pervasive, the more systemic the routines, the greater the degree of spatial interdependence, the stronger is the basis for group level selection. Thank you for clarifying this.

Winter: Actually, as my final point, credit assignment is very important. This multilevel selection issue, the question of how organizations allocate resources internally, is absolutely critical. Because when you think about it, you realize that even if these evolutionary selection pressures are such important drivers, they provide only a very lowdimensional feedback from actual market transactions. And it's the internal workings of organizations that elaborate that limited feedback into promoting some detailed behaviors and suppressing others. So I think that the 
issue you raised there is a very important one. I just think that it's something of a luxury that we get around to the credit assignment problem, because it suggests that some other problems are more or less behind us, which is good.

\section{QUESTIONS FOR THE PANEL}

To deepen this discussion, Johann Peter Murmann solicited questions to probe into the issues raised by the panel. This gave Howard Aldrich, Daniel Levinthal, and Sidney Winter the opportunity to clarify their views.

Question 1: I am skeptical of the idea that there are multiple levels of selection. Doesn't Susan Blackmore's (1999) work show that there is only one level of selection?

Aldrich: A couple weeks ago I posed the celibate priest example to her, and she acknowledged that it made sense. (Richard Dawkins would pass out if he heard her say this. Please don't pass this on, of course, to Richard Dawkins.) She actually said that it does make sense to talk about selection at the group level as well as the individual level.

Question 2: What are the main differences between evolutionary theory and the resource-based theory?

Winter: I have to choose my words carefully for this one. The $\mathrm{RBV}$ is a very flexible theory. I think its popularity and the scope of its application has something to do with that flexibility. Evolutionary theory is still pretty flexible, but not that flexible. I think that in the basic view of the firm, a very important question is whether the category of resources is understood to include processes or routines, as opposed to things that are more in the nature of tradable assets. Some of the analysis offered by the RBV makes perfectly good sense if resources are understood to be tradable assets. It's perhaps ... well, it depends on which article you read, but some articles are very clear about the speculative aspect of that theory. That is to say, you only profit from having these unique resource configurations if you bought the resources cheap, for one reason or another. If it's confined to an analysis where you could think of firms just as portfolios of tradable assets, then it's quite a narrow theory. If you broaden it so that it includes things like routines, then a lot of the analysis about the nature of profitability or competitive advantage begins to look more suspect because very frequently there aren't markets for those things, and you can't understand advantage in the same terms when you have idiosyncratic firm processes among the things that are characterizing the firm. I tried to sort out some of this territory in my paper (Winter, 1995) on the four R's of profitability, which is in the volume edited by Cynthia Montgomery, and also I have long been an admirer of the (Dierickx \& Cool, 1989) paper on asset accumulation and sustained competitive advantage, and I think that paper essentially lays down a foundation where you could understand that evolutionary theory was from that point of view a kind of a branch of the RBV with a particularly strong emphasis on certain kinds of internally created competencies.

Question 3: How does the dynamic capability theory differ from the resource-based theory? How is it different from evolutionary thinking?

Winter: Well, the dynamic capabilities theory is a very prominent illustration of a standing major problem in developing this evolutionary program. That problemalready alluded to here, especially in Dan's commentsis the problem of understanding what is going on in behaviors that on the one hand are clearly patterned and persistent, and systematic in certain kinds of ways, and yet in other ways are addressing and creating novelty and displaying human creativity. Dynamic things like new product development processes are very much of that character-organizations have their ways of doing these things. They are persistent things-you can tell one style from another. In lots of respects those are routinelike features of dynamic capabilities. But on the other hand, the whole point is creating something new. Facilitating creativity is a big part of the story, and I think it's a very great challenge to understand how those things fit together. One other thing I will say about that is that for some reason, perhaps it has something to do with the Teece et. al. (1997) article, I think the term "dynamic capabilities" has acquired a certain aura. As I said before, I don't believe that dynamic capabilities are the key in the sense that if we pursue this idea we will all learn how to make above-average profits. But nevertheless, I think there is still a real phenomenon there, and one that is worthy of a lot of study, and certainly it has been getting some of that.

Question 4: What does the panel think about Maturana's ideas of self-organizing systems? How do complexity theories fit into the evolutionary paradigm?

Aldrich: You reminded me of something I was going to say in response to Sid. I think it's difficult to use evolutionary ideas to look at large firms and to get the same level of understanding from them as you would get if you looked at smaller firms. My argument is that we can learn a heck of a lot more by looking at the fruit flies and not at the condors, or at the crabgrass instead of the redwoods, or whatever other "big" species you could name. You can look at things in a more detailed way in smaller firms.

In my recent book I talked about the movement from nascent entrepreneurs to new organizations and the problem of coherence and boundedness, and how boundaries emerge through communities of practice. Those kinds of things you can see if you follow organizations up from the primeval ooze to coherence. It becomes a lot harder to see such transformations when you switch over to the kinds of firms I think Sid and his colleagues play with, which they call "real firms," and when they say "firms" they mean Fortune 500 companies. They're talking the $.000000001 \%$ that get onto the Fortune 500 list. It's a lot harder in those cases to see this stuff, so I think certainly looking at smaller firms gives us insight into 
these kinds of processes and the coherence problems, and that's where I would say my own efforts are certainly going to go in the future. Beyond that, your question went off in ways that my brain couldn't follow.

Winter: It seems to me a lot of the complexity theory ideas that you reference there may have their proper role in understanding the origins of patterned behavior, which is certainly one very important part of the story. On the other hand, persistence is another very important part of the story, and, at least among the large organizations that Howard has just disparaged, persistence is a very interesting and significant feature. The AT\&Ts, the IBMs, the Boeings, etc., of the world have been around a long time. For a large fraction of the total time that has elapsed since their principal technologies were invented, the people have come and gone, but those organizations have existed as persistent structures that are the society's repositories of particular technological and organizational capabilities. The processes by which they sustain themselves and remain able to command those types of capabilities are a worthy subject of study, too. I don't think those bottom-up complexity ideas are too helpful with this question.

Levinthal: Just as a footnote in response to Howard. If you move beyond birth and death as dependent variables and look, as Sid has, at differential growth rates and worry about the size distribution of firms, then there actually is a lot of action, even amongst these fairly large entities. So while their probability of death is miniscule, shifts in the size distribution are actually nontrivial even among that subpopulation.

Question 5: Sid, don't you think that you are a bit too pessimistic about the role of managers in making a firm successful?

Murmann: Let me tell a little anecdote that speaks about the difficulty of understanding the role of managers. When I was a little kid, I went with my grandfather on a ferry. I saw the captain steer the boat, and I really wanted to do it, too. So I asked him if I could take over the helm for a while. The captain was nice and let me do it. He gave me very clear instructions: Always point the ship to the big tower that you see far away on the horizon; this will get us where we want to go. And so I was steering, but after a while it got really boring. You know, these big ships don't move at all. Just holding the helm and steering the ship in the same direction pretty quickly loses its attraction for a little boy. My grandfather came by and I asked him if he could take over for me. His sense of duty made him stand in for me. But after an hour and a half, Granddaddy was bored, too. He ran to the captain's suite and demanded that someone take over steering the ship. The captain told him in a calm voice that there was no need to worry. The ship had been on autopilot all the time. But Granddaddy and I had been under the impression that we were actually steering the ship. I think this little anecdote illustrates quite nicely what kind of situation managers can be in.

Winter: I'm not sure it's possible to improve on that. That was pretty good. I tried to cover the issue that I think you're raising by saying of course you can't win if you don't play, and playing is a more complicated manner in business than it is in the lottery, and maybe you even learn something about how to play by taking strategy courses. I think that's quite possible. The issue, though, is more like this: If you think that there is useful advice to be conveyed, then here is the thought experiment: You tell me what you need to run this experiment. You want one hour with the CEO? Five hours? A week? You want a research grant for three years before that? Will you bet some of your portfolio by putting it in the stock of the company you're advising because you're confident that if you can only have that audience with the CEO that you can actually change things in the direction that will make that company more profitable? If you try to think in those terms, which is to think of an experimental intervention to see whether a certain kind of advice makes a difference, then I think it is doubtful. Even in the case of lean manufacturing, where the differences in performance were very real, whether the fact that the American automobile companies were "slow" in doing that was basically attributable to their ignorance of what was in strategy journals, or in strategy courses, I think is very doubtful. I think there are other reasons why they were on the course and on autopilot in the way in that Peter just suggested. So I have in mind a rather high standard for demonstrating the power of strategic advice. But even if I'm right in that part of my pessimistic view, that doesn't mean we have nothing to say. I still think we have a lot to say.

Levinthal: I want to add a little bit to the concern raised in this question. Actually, I think, Sid, that some of your own work on replication and some of the work Giovanni Gavetti and I (Gavetti \& Levinthal, 2000) have done has given us the beginnings of that middle ground that I think the question may be hunting for. The notion is that we may have crude templates as to what constitutes useful information. Of course, if that's all you knew you would likely experience quite poor performance. These articulated, codified cognitions aren't enough to take you very far. However, they might set you on what might ultimately emerge as an interesting path. Of course, you might die and be weeded out before you get to effectively execute this new initiative. I think we can begin to explore a little bit the kinds of wildly underspecified suggestions that might affect behavior in possibly dysfunctional and potentially useful ways. Consistent with the lottery imagery, I would not have great confidence necessarily in the expected value of those efforts because they are so underspecified. Ultimately, however, my interest is in the social science problem of understanding how belief structures interact with experiential learning processes rather than the management problem of exactly how good on average such journeys are likely to be.

Question 6: Is social engineering of fitness landscape in fact possible given there may not be enough information, or good information, to actually do this? Is it possible to engineer a coherent system of incentives?

Levinthal: The notion is that you're likely to get it wrong, both the boundedly rational social engineer and the boundedly rational lower agent responding to these structures. What I'm suggesting is that we consider issues of mechanism design by and for boundedly rational actors. 
Question 7: My question to Sid is, Has anything significant happened since 1982? [Editorial Note: This is the year when the Nelson and Winter book came out.]

Winter: There's this new book (Dosi et al., 2000) that just came out .... Well, if you ask if anything has happened that will prevent you from being mugged by economists, the answer is probably no. If you can really get them in a corner, you might be able to embarrass them with the sort of behavioral decision theory results that are very strong and very reproducible. I've seen Dick Thaler do his number on economists, running the experiment in the room with the economists as the subjects and having the standard results come out. But of course, that doesn't make them change their spots the next day.

Levinthal: A minor addition. I don't think anything will prevent the mugging, but I think, along the lines of Sid's comment, that recent work in behavioral game theory is a particularly powerful illustration of the role of bounded rationality because of the presence of competition in those settings. These sorts of experiments differ from early market games, which often were such structured contexts that almost any behavior would lead to a competitive equilibrium. Indeed, Gode and Sunder (1993) have a paper in which they show that in the setting of a simple competitive market, random bidding behavior, subject to budget constraints, leads to the competitive equilibrium. It is not until you explore games where there's a nontrivial interdependence among the actors that outcomes depend on the particular nature of peoples' learning process. Having said this, however, I have to confess to sharing Sid's lack of optimism regarding the avoidance of a mugging.

\section{Question 8: What would a national income account- ing of evolutionary economics look like?}

Winter: The national income accounting part was a metaphor, I think, right? Yes, to advance the science, we need some way to operationalize key variables. We need more careful detailed studies of organizational routines as complex structures above the laboratory level, and we need to address this problem of quantifying the diversity in families of similar routines. If you could do that, then you would have the beginnings of an engine on which you could do statistical analysis and try to relate performance outcomes to the characterization of the routines. So I think that's one very important part of the program. I also think, coming back to some of Dan's themes, that we know remarkably little about how internal resource allocations processes in large organizations operate as a level of selection. We know something about those processes but not a lot, and it's not been placed in this type of framework. That's another area that's really very important and calls for very close examination. I'm sure I could come up with a number of others.

Levinthal: I think one of the challenges is how context dependent are these measures going to be. For instance, in the card game of Michael Cohen's work, it is quite clear what a routine is. But for the national income account you want, some set of context-free measures must be developed. For instance, in general how do firms manage interdependency on the value chain? Expressed this way, the challenge of such "national accounts" is quite daunting. Maybe some folks will come up with some taxonomies of this relatively generic sort. But I think that it's important to recognize that a key part of the patterned behavior of a routine is the context dependence of these behaviors. So I'm not offering a possibility or impossibility statement, but I am flagging how spartan the indicators inevitably are as we rise to these more aggregate levels.

Aldrich: If you're compiling a laundry list, I could add a few elements. One of them is something that Art Stinchcombe mentioned in a review he did on the Web site that Peter runs [www.etss.net]. His argument is that we need more organizational physiologists, or I think a better term might be "organizational ethnographers." We need people who spend lots of time in organizations in a disciplined way and collect systematic information with a reliable accounting scheme. It might go some way toward what we're talking about here. We don't encourage such research among our graduate students.

I don't know why economists figure so heavily into this discussion today. We're in management departments, for goodness sakes! Think about the kind of training our students get. What you should be doing is teaching your students how to be ethnographers-some of your students ought to be doing fieldwork. They ought to be going to anthropology departments and learning how to do fieldwork and do it in a disciplined and systematic way. Not walking into organizations, spending a couple of hours there, and walking out writing a case report. A second thing is computational modeling. Alessandro Lomi and Eric Larsen (2001) have a nice book coming out on computational modeling, looking at some of these issues. You don't have to actually get field data. You don't have to get census data. You can actually build models with realistic assumptions. Some of them come from the lab experiments that Mike Cohen and his colleagues have done. So computational modeling is one possibility.

As I mentioned before, just to repeat, we don't have national accounting data on organizations. It's the most scandalous thing, I think, about our national data accounts. We have an enormous amount of information collected every year from firms of all sizes, even small firms. That information is stored in a way that makes it impossible for us to link it up over time, and so we don't have the ability to create decent pictures of how the economy has evolved. We have cross-sectional snapshots and we have the biggest firms cataloged very well, the publicly traded firms. Well, that's again the 20,000 or so publicly traded firms, the firms that the business schools feature in their teaching. However, the larger population of small and medium-sized organizations is recorded and then filed away and forgotten. We need to put more money into building these data sets that allow us to link firms over time. Thus, those are three other possibilities that would improve the data available to us. This is pie in the sky, of course, but actually, the part that's not pie in the sky is training more people to do field work. That you could do. You all have anthropology departments on your campus. Send a few of your brightest students over there and have them learn fieldwork techniques.

Question 9: Is there a theory of the firm in evolutionary economics? 
Winter: Well, the aforementioned 1982 book did not say that it was advancing a theory of the firm. My problem with the question, though, is that I don't think anybody has a theory of the firm. The reason I think that is that to my mind, one of the most salient characteristics of that puzzle is the fact that firms, as legal entities, can be put together by mergers according to the impulse of investment bankers and the marketing of investment bankers. There is an industry of putting firms together and taking them apart again. So if by a firm you meant the results of that process, then you would have to understand how the firm-putting-together-and-taking-apart industry does its work, which is not a subject, as far as I can see, that's being addressed by any of the alleged contenders for the theory of the firm. Now, on the other hand, if you don't mean to refer to the reality that is out there, the things that these investment bankers put together for longer or shorter periods of time, then you ought to be clear about that. You could have a perfectly respectable scientific approach that says that I've got a theory of the firm here, but Citigroup isn't an example. It's not one of those firms that my theory is about, that's something the investment bankers did. That would be a respectable approach to the problem: to have an idea about a firm in which not all the commonly recognized instances out there in the economy were actually examples of firms as understood in the theory. But again, I don't see people doing that. So I don't know where they stand on that basic issue. And I think it's a very fundamental issue, and from an evolutionary point of view, the evolutionary point of view as contrasted to neoclassical or rationalistic point of view, any dumb thing can happen for a while. Insofar as investment bankers decide to do dumb things, those things happen for a while, and the question is not whether there are some dumb things out there in the world, but how long they last, and what are the processes that eliminate them. So that's a somewhat different agenda from the standard theory of the firm question.

Levinthal: Along those lines, and what I tried to point to in my initial remarks, I would phrase the question somewhat differently: Is the firm an important unit of selection? Is evolutionary theory about the selection of particular routines or traits, and are firms simply carriers of these properties, or is what is being selected truly a group-level property?

Question 10: How come the panel talked so much about selection and not the more important process of variation?

Aldrich: I think selection logic is what most cleanly separates evolutionary theory from the other kinds of theories in management. Most papers that you will read talk about variation, and, in fact, most of them will talk about retention. They're talking about management systems. They're talking about retention, persistence, and reproduction replication. That's a fairly common theme. Variation is also a fairly common theme. What you don't hear so much of is selection. So when I talk to people who aren't evolutionary in their thinking, the first thing I stress to them is the importance of selection logic. I tell them a story like my chicken-beak story just to get them to think about what it would mean to take a selection argument seriously. There's no evolutionary theory with- out a theory of variation. It's very clear. You don't have something to select unless you've got coherent units that are out there to be selected for, or selected within, or whatever. Don't take our discussion here as any sign of an imbalance of thinking by evolutionary theorists; it's a chance event.

Winter: From the point of view of the economics discipline, you know, you raise a very important point. There's a huge difference between the neoclassical, orthodox perspective in economics on what the market system is doing for you and the perspective in evolutionary theory. In evolutionary theory the story is, the market system is a device such that when new opportunities and new problems come up, a bunch of different actors have incentives to think up solutions and try them. Some of those solutions are better than others, and the market system functions in such a way as to promote, at least in a crude sense, superior solutions and suppress the less desirable solutions. That is a story about how society goes about solving its ever-changing economic problems; that is a completely different story than the story that orthodox economics tells about efficient allocations. In the evolutionary story, obviously, the experimentation and the generation of variety is a very important element. Organizational arrangements that might look entirely sensible in a world in which you thought there were no more new problems to solve look terrible in the perspective of a world in which there are always new problems to solve and which you need experimentation and you need to have people with strong incentives to try to come up with new solutions. I think that it's a very good thing that you raised that issue.

Question 11: If the efficient market process selects only the best players, how is that idea consistent with Howard's statement that sometimes individual fitness may be inconsistent or may work against the fitness of the group? And if the group is the important economic unit, how would that square with the market doing its work properly?

Winter: I think if I understood your question correctly, the reference to efficient market mechanisms goes back to what I just said, which is, the market sorts out the more desirable solutions to problems and suppresses the undesirable ones, as opposed to other connotations of the term "efficient markets" from finance or elsewhere. On that assumption as to what the question is about, the multilevel selection issue is quite relevant in that, for example, orthodox economics has a long tradition of hostility to industry-level organization, seeing cartelization everywhere, basically. It says since we know from the textbook theorems that all we need is independently acting competitive firms in order to achieve nirvana, it must be that anytime you see industry-level organization that this is perverse and undesirable. I have to say that as a part-time political analyst, I think the standard orthodox view on industry-level organization should not be neglected. It may well be cartelization in disguise. But I think, nevertheless, that it's pretty clear that in many cases industries have been made to function better because some check was imposed by a higher level of organization, whether it was in setting standards or setting rules for fair competi- 
tion, and so on. So I think, in fact, the evolutionary perspective is open to a constructive role for more levels of organization than is characteristic in the orthodox theory.

Murmann: I want to thank everyone for this stimulating debate. What has emerged-at least for me-from our conversation is a research agenda that will keep us busy perhaps not the entire third millennium but certainly a good many years to come.

\section{REFERENCES}

Adler, P. (1993). The learning bureaucracy: New United Motor Manufacturing Inc. In Barry Staw \& Lary Cummings (Eds.), Research in organizational behavior (Vol. 15, pp. 111-194). Greenwich, CT: JAI.

Aldrich, H. E. (1979). Organizations and environments. Englewood Cliffs, NJ: Prentice Hall.

Aldrich, H. (1999). Organizations evolving. London: Sage.

Amburgey, T. L., \& Rao, H. (1996). Organizational ecology: Past, present, and future directions. Academy of Management Journal, 39(5), 1265-1286.

Barney, J. B. (1991). Firm resources and sustained competitive advantage. Journal of Management, 17(1), 99-120.

Baum, J. A. C., \& McKelvey, B. (Eds.). (1999). Variations in organization science: In honor of Donald T. Campbell. Thousand Oaks, CA: Sage.

Baum, J. A. C., \& Singh, J. V. (Eds.). (1994). The evolutionary dynamics of organizations. New York: Oxford University Press.

Bowman, E. H., \& Helfat, C. E. (2001). Does corporate strategy matter? Strategic Management Journal, 22(3), 1-23.

Blackmore, S. J. (1999). The meme machine. New York: Oxford University Press.

Burgelman, R. A. (1991). Intraorganizational ecology of strategy making and organizational adaptation: Theory and field research. Organization Science, 2(3), 239-262.

Burgelman, R. A. (1994). Fading memories: Strategic business exit in dynamic environments. Administrative Science Quarterly, 39, 24-56.

Campbell, D. T. (1960). Blind variation and selective retention in creative thought as in other thought processes. Psychological Review, 67, 380-400.

Campbell, D. T. (1969). Variation and selective retention in socio-cultural evolution. General Systems, 14, 69-85.

Cantner, U., Hanusch, H., \& Klepper, S. (2000). Economic evolution, learning, and complexity. Heidelberg, Germany: Physica-Verlag.

Carroll, G. R., \& Hannan, M. T. (2000). The demography of corporations and industries. Princeton, NJ: Princeton University Press.

Clark, K. B., Chew, W. B., \& Fujimoto, T. (1987). Product development in the world auto industry. Brookings Papers on Economic Activity, 3, 729-771.

Cohen, M. D., \& Bacdayan, P. (1994). Organizational routines are stored as procedural memory: Evidence from a laboratory study. Organization Science, 5(4), 554-568.

Cyert, R. M., \& March, J. G. (1992). A behavioral theory of the firm. Cambridge, MA: Basil Blackwell. (Original work published 1963)
Dawkins, R. (1976). The selfish gene. New York: Oxford University Press.

Dierickx, I., \& Cool, K. (1989). Asset stock accumuation and sustainability of competitive advantage. Management Science, 35(12), 1504-1511.

Dosi, G. (2000). Innovation, organization and economic dynamics: Selected essays. Northampton, MA: Edward Elgar.

Dosi, G., Nelson, R. R., \& Winter, S. G. (2000). The nature and dynamics of organizational capabilities. New York: Oxford University Press.

Dosi, G., \& Winter, S. G. (2002). Interpreting economic change: Evolution, structures and games. In M. Augier and J. G. March (Eds.), The economics of choice, change and organizations: Essays in honor of Richard M. Cyert (pp. 337353). Cheltenham, UK: Edward Elgar.

Foss, N. J. (1993). Theories of the firm: Contractual and competence perspectives. Journal of Evolutionary Economics, 3(2), 127-144.

Foss, N. J. (1997). Evolutionary and contractual theories of the firm: How do they relate? Rivista Internazionale di Scienze Sociali, 105(3), 309-337.

Gavetti, G., \& Levinthal, D. (2000). Looking forward and looking backward: Cognitive and experiential search. Administrative Science Quarterly, 45(1), 113-138.

Gode, D. K., \& Sunder, S. (1993). Allocative efficiency of markets with zero-intelligence traders: Market as a partial substitute for individual rationality. Journal of Political Economy, 101(1), 119-137.

Hannan, M. T., \& Freeman, J. H. (1977). The population ecology of organizations. American Journal of Sociology, 82, 929-964.

Hannan, M. T., \& Freeman, J. H. (1984). Structural inertia and organizational change. American Sociological Review, 49, 149-164.

Herriott, S. R., Levinthal, D., \& March, J. G. (1985). Learning from experience in organizations. American Economic Review, 75(2), 298-302.

Holbrook, D., Cohen, W. M., Hounshell, D. A., \& Klepper, S. (2000). The nature, sources, and consequences of firm differences in the early history of the semiconductor industry. Strategic Management Journal, 21(10/11), 1017-1041.

Klepper, S. (1997). Industry life cycles. Industrial and Corporate Change, 6(1), 145-182.

Klepper, S., \& Simons, K. L. (1997). Technological extinctions of industrial firms: An inquiry into their nature and causes. Industrial and Corporate Change, 1997(2), 379-460.

Klepper, S., \& Simons, K. L. (2000a). Dominance by birthright: Entry of prior radio producers and competitive ramifications in the U.S. television receiver industry. Strategic Management Journal, 21(10/11), 997-1016.

Klepper, S., \& Simons, K. L. (2000b). The making of an oligopoly: Firm survival and technological change in the evolution of the U.S. tire industry. Journal of Political Economy, 108(4), 728-760.

Kogut, B., \& Zander, U. (1992). Knowledge of the firm, combinative capabilities, and the replication of technology. Organization Science, 3, 383-397.

Langton, J. (1984). The ecological theory of bureaucracy: The case of Josiah Wedgwood and the British pottery industry. Administrative Science Quarterly, 29(3), 330-354. 
Levinthal, D. (1992). Surviving Schumpeterian environments: An evolutionary perspective. Industrial and Corporate Change, 1(3), 427-443.

Levinthal, D. (1997). Adaptation on rugged landscapes. Management Science, 43, 934-950.

Levinthal, D. A., \& March, J. G. (1993). The myopia of learning. Strategic Management Journal, 14[Special Issue], 95-112.

Lomi, A., \& Larsen, E. R. (Eds.). (2001). Dynamics of organizations: Computational modeling and organization theories. Menlo Park, CA: AAAI Press/MIT Press.

March, J. G. (1999). The pursuit of organizational intelligence. Malden, MA: Blackwell Business.

March, J. G., \& Simon, H. A. (1958). Organizations. New York: Wiley.

McGahan, A. M., \& Porter, M. E. (1997). How much does industry matter, really? Strategic Management Journal, 18 , 15-30.

McKelvey, B. (1982). Organizational systematics: Taxonomy, evolution and classification. Berkeley: University of California Press.

Murmann, J. P. (in press). Knowledge and competitive advantage: The coevolution of firms, technology, and national institutions. New York: Cambridge University Press.

Murmann, J. P., \& Homburg, E. (2001). Comparing evolutionary dynamics across different national settings: The case of the synthetic dye industry, 1857-1914. Journal of Evolutionary Economics, 11, 177-205.

Nelson, R. R., \& Winter, S. G. (1982). An evolutionary theory of economic change. Cambridge, MA: Belknap/Harvard University Press.

Pfeffer, J. (1993). Barriers to the advance of organizational science: Paradigm development as a dependent variable. Academy of Management Review, 18(4), 599-620.

Rumelt, R. P. (1991). How much does industry matter? Strategic Management Journal, 12(3), 167-185.

Saviotti, P., \& Metcalfe, J. S. (1991). Evolutionary theories of economic and technical change. Reading, MA: Academic Publishers.

Schmalensee, R. (1985). Do markets differ much? American Economic Review, 75(3), 341-351.

Schumpeter, J. (1934). The theory of economic development. Cambridge, MA: Harvard University Press.

Schumpeter, J. A. (1950). Capitalism, socialism and democracy. New York: Harper \& Row. (Original work published 1942)

Silverberg, G., \& Soete, L. (Eds.). (1994). The economics of growth and technical change: Technologies, nations, agents. Aldershot, UK: Elgar.

Simon, H. (1976). Administrative behavior (3rd ed.). New York: Macmillan.

Singh, J. V., \& Lumsden, C. J. (1990). Theory and research in organizational ecology. Annual Review of Sociology, 16, 161-195.

Sober, E., \& Wilson, D. S. (1998). Unto others: The evolution and psychology of unselfish behavior. Cambridge, MA: Harvard University Press.

Szulanski, G. (1996). Exploring internal stickiness: Impediments to the transfer of best practice within the firm. Strategic Management Journal, 17 [Special Issue], 27-43.
Szulanski, G. (2000). Appropriability and the challenge of scope: Banc One routinizes replication. In G. Dosi, R. R. Nelson, \& S. G. Winter (Eds.), The nature and dynamics of organizational capabilities (pp. 69-98). New York: Oxford University Press.

Teece, D. J., Pisano, G., \& Shuen, A. (1997). Dynamic capabilities and strategic management. Strategic Management Journal, 18(7), 509-533.

Usselman, S. W. (1993). IBM and its imitators: Organizational capabilities and the emergence of the international computer industry. Business and Economic History, 22, 1-35.

Van Maanen, J. (1995). Style as theory. Organization Science, 6(1), 133-143.

Weick, K. E. (1979). The social psychology of organizing. Reading, MA: Addison-Wesley.

Wernerfelt, B. (1984). A resource-based view of the firm. Strategic Management Journal, 5, 171-180.

Winter, S. (1994). Organizing for continuous improvment: Evolutionary theory meets the quality revolution. In J. Singh \& J. Baum (Eds.), The evolutionary dynamics of organizations (pp. 90-108). New York: Oxford University Press.

Winter, S. (1995). Four Rs of profitability: Rents, resources, routines and replication. In C. A. Montgomery (Ed.), Resource-based and evolutionary theories of the firm: Towards a synthesisc (pp. 147-178). Boston: Kluwer Academic Publishers.

Witt, U. (Ed.). (1993). Evolutionary economics. Aldershot, U.K.: Elgar.

Zander, U., \& Kogut, B. (1995). Knowledge and the speed of the transfer and imitation of organizational capabilities: An empirical test. Organization Science, 6(1), 1-17.

Zollo, M., \& Winter, S. G. (2002). Deliberate learning and the evolution of dynamic capabilities. Organization Science, 13(3), 339-351.

HOWARD E. ALDRICH (Ph.D., University of Michigan) is Kenan Professor of Sociology, chair of the Management and Society Curriculum, and adjunct professor of management, Kenan-Flagler Business School at the University of North Carolina, Chapel Hill. He has published articles on evolutionary theory, organizations, entrepreneurship, small business, ethnic relations, and organizational strategy. In January 2000 he won the Entrepreneurship Researcher of the Year Award, presented by the Swedish Foundation of Small Business Research. He has also been awarded the Distinguished Career of Scholarly Achievement award by the Organization and Management Division of the Academy of Management. In February 2002 he was presented with the Caryle Sitterson Award for Outstanding Teaching at the University of North Carolina, Chapel Hill. He is the author of Organizations and Environments (Prentice Hall, 1979), Population Perspectives on Organizations (Uppsala University Press, 1986), and coauthor with Roger Waldinger and Robin Ward of Ethnic Entrepreneurs: Immigrant Business in Industrial Societies (Sage, 1990). His latest book, Organizations Evolving (Sage, 1999), won the Academy of Management George Terry Award as the best management book published in 1998-1999 and was cowinner of the American Sociological Association's Section on Organizations, Occupations, and Work Max Weber Award as the best book published in 1997-1999.

DANIEL LEVINTHAL is the Julian Aresty Professor of Management and Economics at the Wharton School, University of Pennsylvania. He 
received his Ph.D. from the Graduate School of Business, Stanford University, in 1985. Levinthal taught at the Graduate School of Industrial Administration, Carnegie Mellon University, from 1983 to 1989. Since 1989 Levinthal has been a faculty member at Wharton. His research interests focus on issues of organizational adaptation and industry evolution, particularly in the context of technological change.

JOHANN PETER MURMANN is assistant professor of management and organizations at the Kellogg School of Management, Northwestern University. He received a B.A. in philosophy from the University of California, Berkeley (1990) and a Ph.D. in management of organizations from Columbia University (1997). His main interest lies in the development of evolutionary theories for industrial phenomena. He recently completed a book that will appear at Cambridge University Press under the title of
Knowledge and Competitive Advantage: The Coevolution of Firms, Technology and National Institutions. He is the editor of Evolutionary Theories in the Social Sciences (www.etss.net).

SIDNEY G. WINTER is the Deloitte and Touche Professor of Management at The Wharton School of the University of Pennsylvania and codirector of its Reginald H. Jones Center for Management Policy, Strategy and Organization. He previously served as chief economist of the U.S. General Accounting Office and in faculty positions at Yale, Michigan, and the University of California, Berkeley. He is a graduate of Swarthmore College and received the M.A and Ph.D. degrees from Yale. A fellow of the Econometric Society and the American Association for the Advance of Science, he has focused his research in the areas of firm behavior and capabilities, industry evolution, and technological change. 